
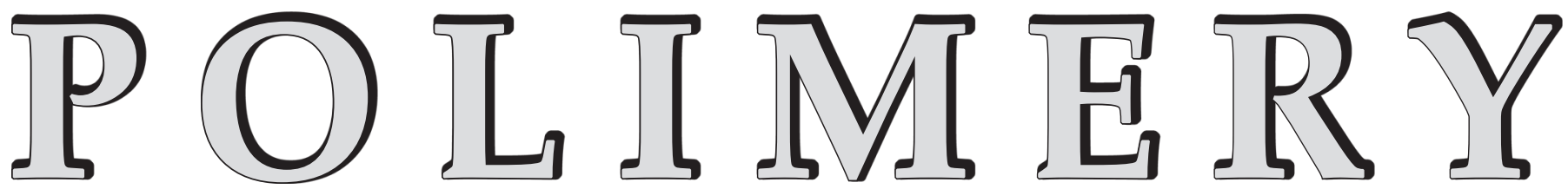

\title{
Influence of mold design and injection parameters on warpage deformation of thin-walled plastic parts
}

\author{
Bo Wang ${ }^{1), 2)}$ (ORCID ID: 0000-0002-5961-9639), Anjiang Cai ${ }^{1), ~ *) ~(0000-0001-7175-609 X) ~}$ \\ DOI: dx.doi.org/10.14314/polimery.2021.5.1
}

\begin{abstract}
Thin-walled plastic parts are susceptible to deformation during injection molding. Using the example of a notebook battery cover, optimization of the injection mold design and injection process parameters was performed with Moldflow software, which resulted in about $69 \%$ reduction of the deformations. Moreover, the uneven material shrinkage during the injection process has been shown to be the main cause of deformations of thin-walled plastic parts.
\end{abstract}

Keywords: injection molding, warpage deformation, mold design, process parameters

\section{Wpływ konstrukcji formy i parametrów procesu wtryskiwania na odkształcenia cienkościennych elementów z tworzyw polimerowych}

\begin{abstract}
Streszczenie: Cienkościenne elementy z tworzyw polimerowych są podatne na odkształcenia podczas formowania metodą wtryskiwania. Na przykładzie pokrywy baterii notebooka dokonano optymalizacji konstrukcji formy wtryskowej oraz parametrów procesu wtrysku w programie Moldflow, co pozwoliło na zmniejszenie odkształceń o około $69 \%$. Ponadto wykazano, że nierównomierny skurcz materiału podczas procesu wtryskiwania jest główną przyczyną deformacji cienkościennych elementów z tworzyw polimerowych.
\end{abstract}

Słowa kluczowe: wtryskiwanie, odkształcenie, konstrukcja formy, parametry procesu

Injection molding is considered to be one of the most important processes in the plastics industry due to its stable quality, economic efficiency and the ability to manufacture complex products with high precision. Injection molded products with a flow length to thickness ratio above 100 are called thin-walled plastic parts [1-3]. Thin-wall injection molding is a new technology based on ordinary injection molding that has developed over recent years. Due to the thinner wall thickness of plastic parts,

\footnotetext{
1) School of Mechanical and Electrical Engineering, Xi'an University of Architecture and Technology, Xi'an 710055, China.

2) School of Aerocraft, Xi'an Aeronautical University, Xi'an 710077, China.

*) Author for correspondence: 21138481@qq.com
}

cooling of the molten polymer in the mold cavity will be accelerated, making molding and quality control of plastic parts difficult. Thin-walled plastic parts are prone to defects such as warpage, short shots, weld lines, burring, and air traps during the molding process. Among them, warpage has the most significant effect on the size of plastic parts, and excessive warping deformation will cause deviation from the dimensions of the plastic parts design requirements and become waste products [4-5]. Therefore, the improvement of thin-walled plastic parts warping has become the focus of widespread attention in the industry. The structure of the plastic part, the mold design, and the injection molding process parameters are the main factors affecting the warpage of thin-walled plastic parts. Generally, the shape of the plastic parts 
cannot be changed. Due to the design requirements of the product, the purpose of improving the molding quality of plastic parts can only be achieved from the mold design and injection molding process parameters. Many researchers have done a lot of research in this area. Lee and Kim [6] studied the influence of process conditions and mold design on warpage and stated that changing the gate position can significantly affect warping of plastic parts. Xie et al. [7] found that the wrong geometry or size of the runner will change the properties of the molten plastic, resulting in an imbalanced injection of materials into the cavities. If the temperature distribution inside the cavity is not uniform, it will increase the possibility of warpage and residual stress for the injected parts. Yen et al. [8] used finite element and neural networks to control the warpage of plastic parts by changing the diameter and length of the runner. Hassan et al. [9] proposed a mold cooling system as another factor that effects the warpage of molded parts, and they pointed out that the position of the cooling system leads to changes in the shrinkage rate and the temperature of the final product.

In a conventional method, for each new product, manufacturers of plastic products by injection molding obtain appropriate process parameters (limiting deformations) as a result of long and expensive tests. Fortunately, with the development of science and technology, ComputerAided Engineering (CAE) software such as Moldflow, Z-mold, and Moldex appeared, which can help manufacturers to repeatedly test the processing parameters of plastic parts, and greatly improve the work efficiency and reduce the costs [10-12]. A lot of research was done to eliminate warping by optimizing the molding parameters. Ozcelik and Sonat [13] performed warpage analysis using Moldflow CAE software platform and they found that injection pressure has the biggest influence on warping. Lotti et al. [14] used Moldflow software to simulate the shrinkage performance of injection molded polypropylene products, and the results showed that the injection pressure and mold temperature are the main factors of injection molding products shrinkage. Patcharaphun et al. [15] compared the data obtained from Moldflow software using to simulate the molding process parameters with experimental data, that verified the reliability of the simulation results. Through the design of experiment, the process parameters were optimized, and the warpage of the products was significantly reduced. Gao and Wang [16] proposed an optimization method based on the Kriging surrogate model to minimize the warpage of injection molded parts. According to the Kriging surrogate model, combining the design of experiment (DOE) methods is used to build an approximate relationship between warpage and the process parameters, replacing the expensive simulation analysis in the optimization iterations. Shi et al. [17] proposed an adaptive optimization method to minimize the warpage of the injection molding parts based on a neural network. Moayyedian et al. [18] developed an effective optimization method using fuzzy quality evaluation and Taguchi experimental design to minimize the warpage value of injection molded plastic products.

All cited researchers accomplished their purpose of either improving the molding design or optimizing the process parameters to significantly minimize the warpage of the injection molding product through a number of optimization methods. However, the mold design and the injection molding process parameters are the main factors affecting the warpage of thin-walled plastic parts, only optimizing one aspect to minimize the warpage of plastic parts may not be the best. Therefore, if improvements can be made from both the mold structure and process parameters, the effect of reducing the warpage of the plastic part will be more significant.

In this study, in order to reduce the warpage deformation of thin-walled plastic parts, both the mold design and the molding process parameters were optimized. Taking the injection molding production of the notebook battery cover as an example, Moldflow software was adopted to simulate the forming process of this thin-walled part to determine the gating system and mold cooling system at the mold design stage. The cavity filling time, weld line creation in parts, and air pocket position during injection molding were analyzed, and used as a reference for the detailed mold design. A new method using a multi-factor orthogonal test was proposed. Based on the injection molding simulation software, 16 simulation tests were adopted to obtain the warpage deformation of the notebook battery cover under four levels and five factors such as: melt temperature, mold temperature, injection time, hold time, and holding pressure. The degree of influence of 5 process parameters on the amount of warpage deformation was compared using range analysis and variance analysis to obtain an optimized combination of molding process parameters to minimize warping of the battery cover.

\section{EXPERIMENTAL PART}

\section{Materials}

Lexan polycarbonate (PC) was used as the molding material. The material grade is bpl1000. Its density is $1.2 \mathrm{~g} / \mathrm{cm}^{3}$ and its shrinkage is $0.35 \%$. Detailed material properties are given in Table 1.

For battery cover manufacturing, a Sumitomo SE130HSZ high-speed injection molding machine was used.

T a b l e 1. PC properties

\begin{tabular}{l|c}
\hline \multicolumn{1}{c|}{ Property } & Value \\
\hline Molded part shrinkage, $\%$ & $0.3-0.7$ \\
Solid density, g/cm ${ }^{3}$ & 1.2 \\
Tensile modulus, MPa & 2460 \\
Flexural modulus, MPa & 2360 \\
Thermal conductivity, W/mK & 0.19 \\
\hline
\end{tabular}




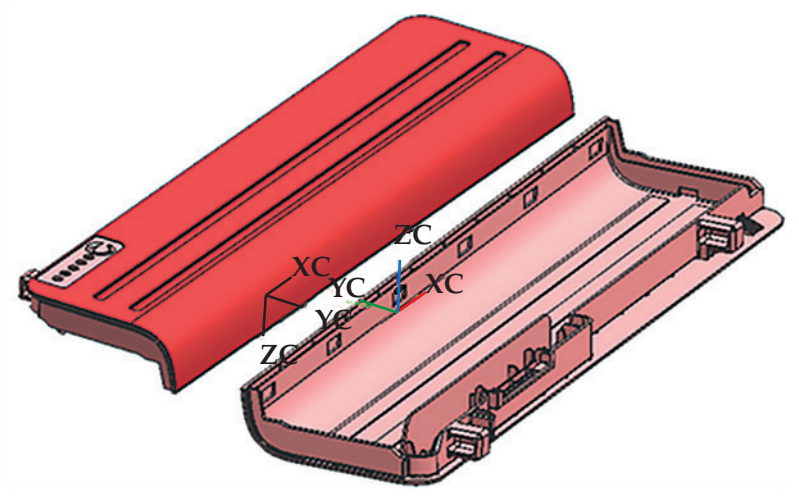

Fig.1. Battery cover three-dimensional model

\section{Design analysis of battery cover}

The battery cover used in this study is shown in Fig. 1. Its length, width and height are $206 \mathrm{~mm}, 55.2 \mathrm{~mm}$ and $16.2 \mathrm{~mm}$, respectively. The maximum warpage of plastic parts should not exceed $0.2 \mathrm{~mm}$. The surface of the battery cover should be smooth without any gate marks. Using the MPA module in Moldflow to analyze the wall thickness of the battery cover, as shown in Fig. 2, it can be seen that the maximum wall thickness of the plastic part is $2.35 \mathrm{~mm}$ and the average wall thickness is $0.8 \mathrm{~mm}$. It can be seen that it is a thin-walled plastic part. The wall thickness of the product varies widely and is prone to warping and deformation.

\section{Mold design optimization}

According to the number of cavities, the mold can be divided into a single-cavity mold and multi-cavity mold. The feature of single-cavity molds is high precision of plastic parts, low manufacturing cost, short injection molding cycle, but a high cost of plastic parts and low productivity, making it suitable for cases requiring high precision plastic parts. The characteristics of multi-cavity molds are complex mold structure, high production efficiency, low precision of plastic parts, high mold manufacturing cost and long injection molding cycle [19]. The battery cover is a small plastic part requiring high precision, and there are inverted buckles in the part design, so a lateral slider mechanism is needed. In order to reduce the complexity of the mold and ensure the dimensional

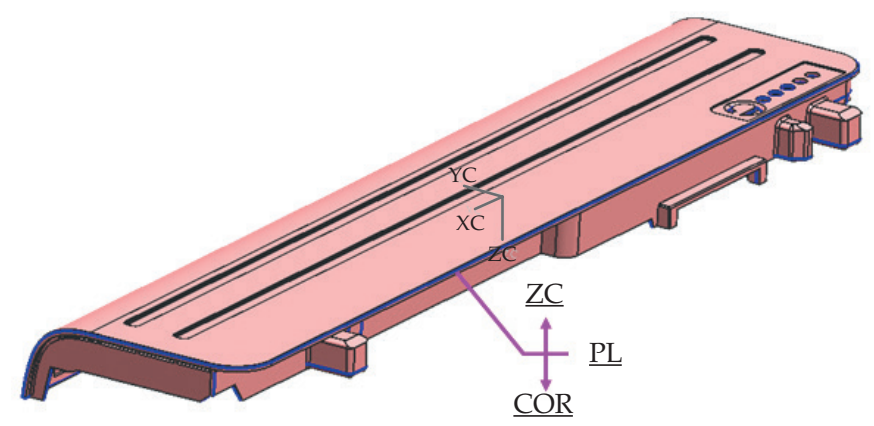

Fig. 3. Parting line of battery cover

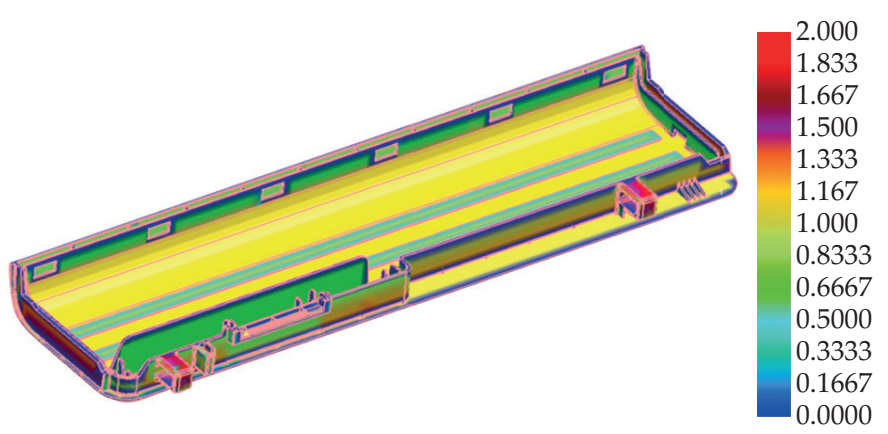

Fig. 2. Battery cover wall thickness analysis

accuracy of the plastic part, a single-cavity mold structure was adopted [20].

The separable contact surface used to remove the plastic part from the mold is called the parting line. When determining the parting line, it is necessary to consider the position of the plastic part in the mold, the design of the cavity feeding system, the structural manufacturability and accuracy of the plastic part, the manufacturing of the mold, the mold venting, and other factors, combined with the design of the battery cover features. The selected parting line is shown in Fig. 3.

\section{Determination of the feeding system}

The feeding system is the most important part of the mold design. The molten material fills the mold cavity through the feeding system and transmits the injection pressure to all parts of the cavity [21]. Reasonable setting of the feeding system affects the quality of the parts. Choosing the appropriate gate position and gate number can not only improve the molding efficiency, but also ensure the quality of the part. The gate cannot be set on the surface of the battery cover due to the requirement of its smooth appearance, and the battery cover structure is a thin-walled part, the pressure required during injection is relatively high, so a latent horn gate pouring was selected. This kind of gate can be automatically separated from the plastic part under the pulling force of the template when the mold is opened. Moreover, since the crosssection of the gate is larger than that of the feeding gate at the end of the horn, the gate can hold the pressure for a long time during the injection and prevent the spraying phenomenon. The latent horn gate must be equipped with the Rib feeding system to assist feeding. The Rib feeding system can be removed by a punching jig after the plastic part is formed, which can ensure that no pouring marks are left on the surface of the battery cover. The design of the battery cover is asymmetrical, according to engineering experience, the number of gates should be set to an odd number to ensure that the mold cavity is filled quickly and evenly by the molten material [22]. The number of gates selected in this study was 5 . The diameter of the gate cross-section at the connection with the 
Less than or equal to $15 \mathrm{~mm}$
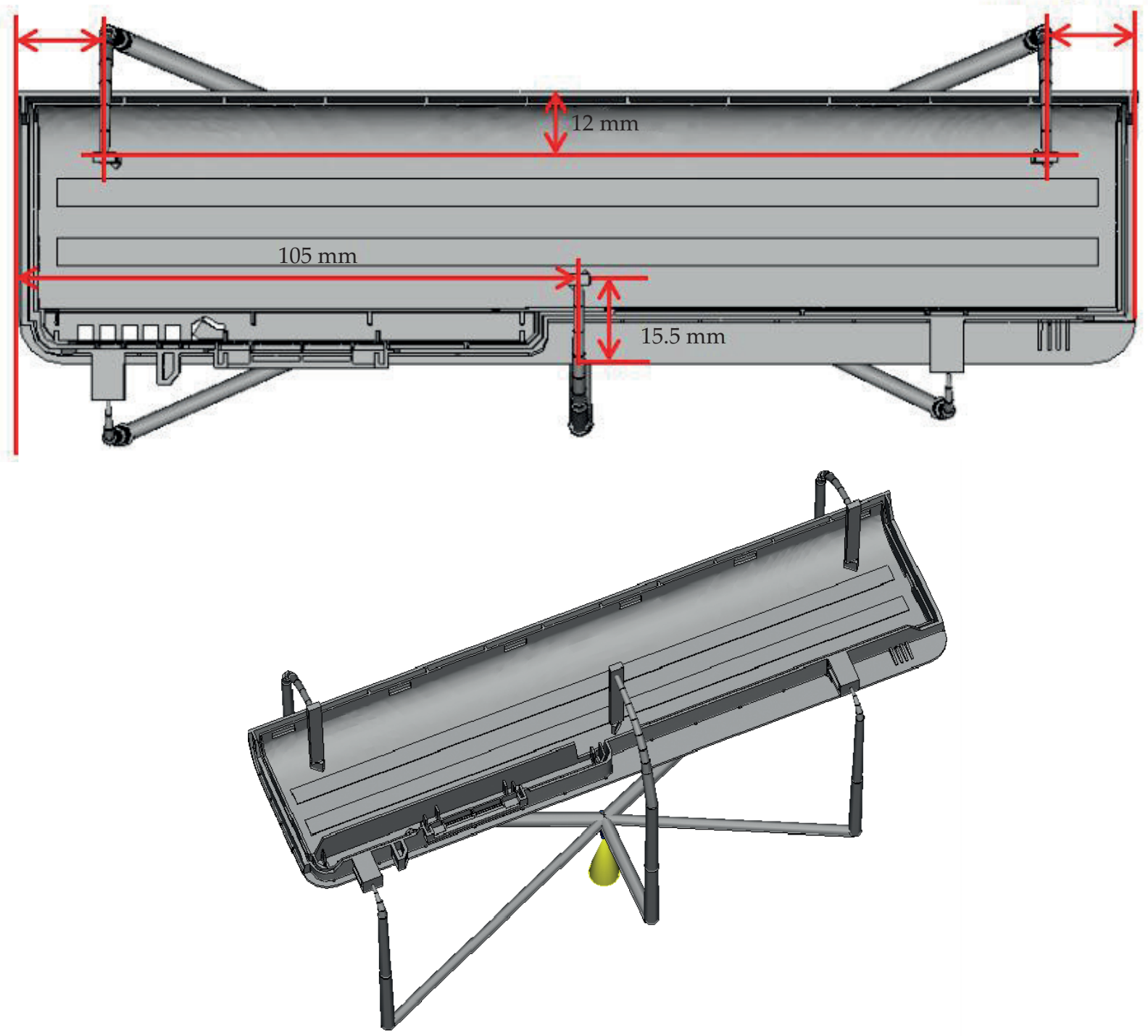

Fig. 4 . The battery cover mold feeding system

$\mathrm{Rib}$ is $1.5 \mathrm{~mm}$, and the diameter of the gate cross-section at the connection with the shunt runner is $5 \mathrm{~mm}$. Figure 4 shows the feeding system of the battery cover mold.

\section{Determination of the cooling system}

The mold temperature and melt temperature directly affect the molding quality and production efficiency of plastic parts. Controlling the mold temperature can not only ensure the plastic part evenly cool and prevent warping, but also shorten the molding cycle and improve the production efficiency [23]. The cooling system controls and regulates the mold temperature. Therefore, a reasonable set of cooling systems is very important for the injection mold. The melting point of polycarbonate is about $280^{\circ} \mathrm{C}$, and the temperature is about $65^{\circ} \mathrm{C}$ after

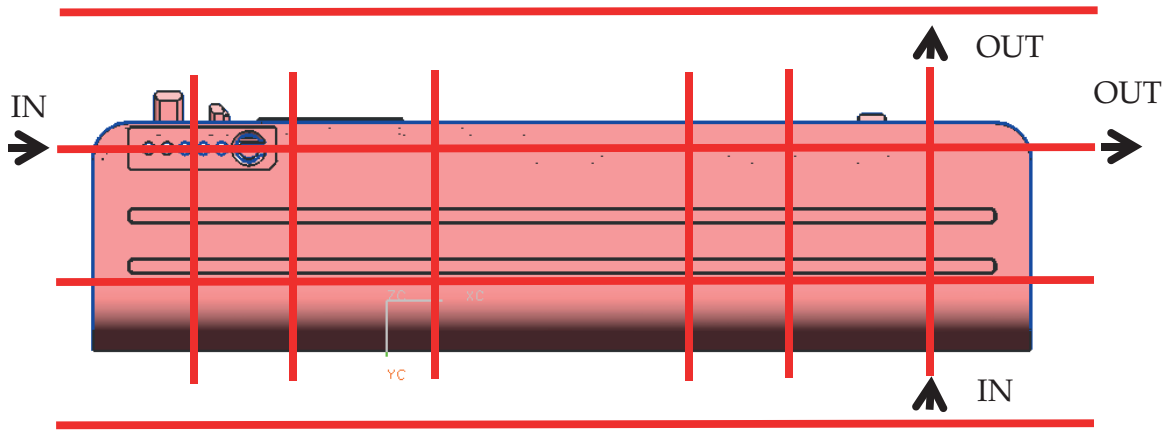

Fig. 5. Cooling water channels in the cavity 


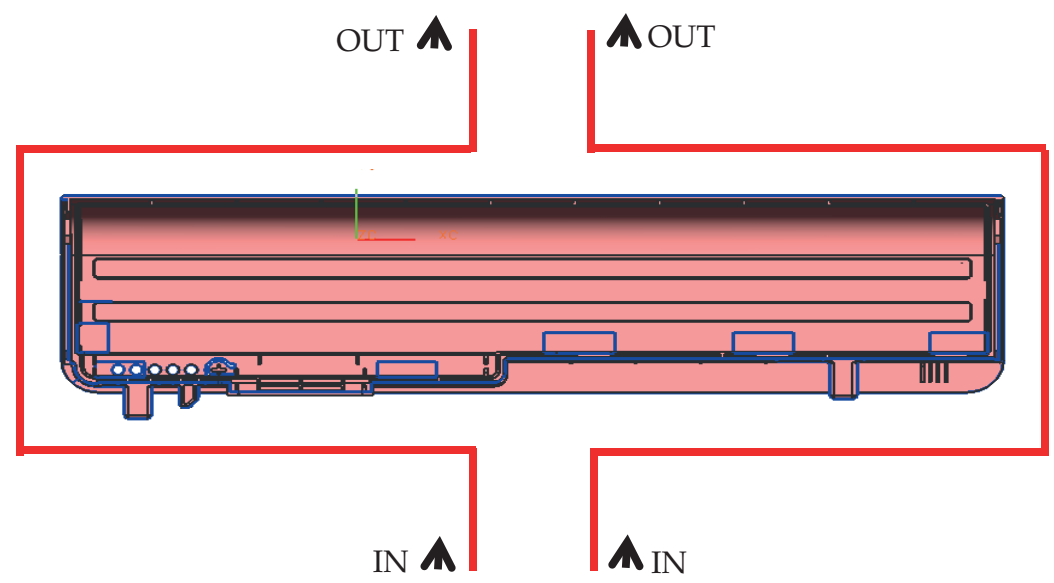

Fig. 6. Cooling water channels in the core

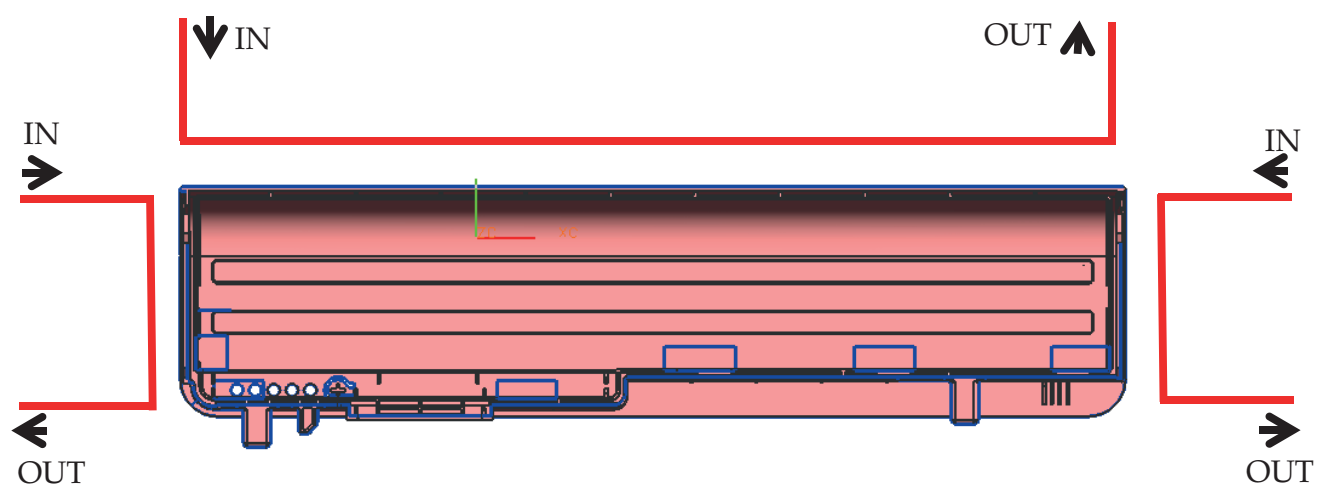

Fig. 7. Cooling water channels in the slider

it is solidified into plastic parts in the mold. In order to quickly solidify the molten material in the mold cavity, a reasonable cooling system must be set up on the mold to take away the large amount of heat generated by the melt during solidification. In this study, the cooling water channels are set on the core, cavity, and slider, and the cooling medium is water. Two layers of channels are set in the mold cavity, the first layer is 6 water channels, and the second layer is 6 water channels, as shown in Fig. 5 . Two layers of water channel are set on the core, the first

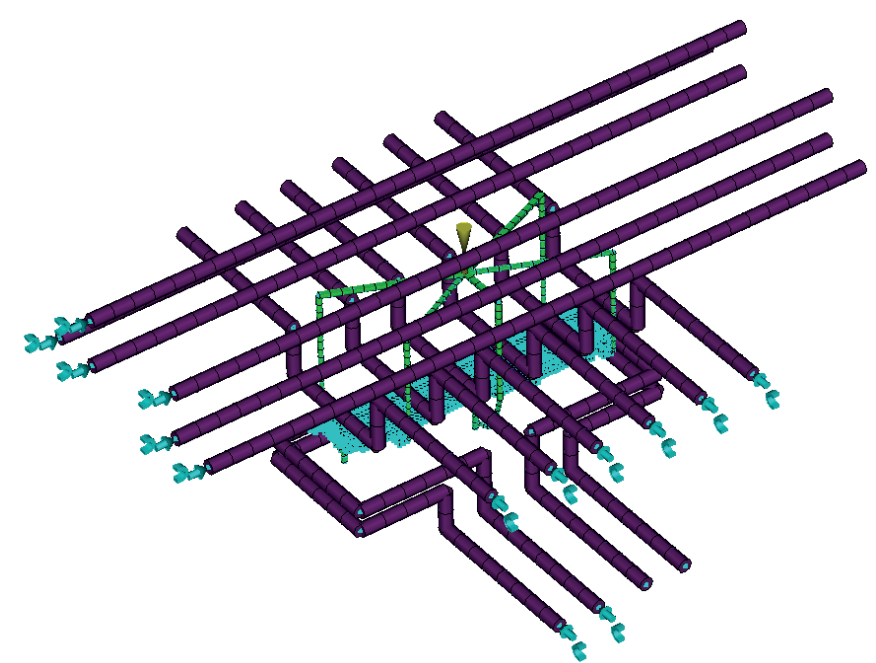

Fig. 8. Battery cover FE model established under Moldflow software environment layer is 1 water channel surrounding the battery cover, the second layer is 1 water channel, which is set on the slider, as shown in Fig. 6 and Fig. 7. The cooling system has 14 water channels, all of which are $10 \mathrm{~mm}$ in diameter.

\section{FE simulation of battery cover}

The battery cover FE model was established under the Moldflow software environment. Moldflow is good at simulating the injection molding process of the plastic part. The FE model includes 12,247 triangle elements, mesh condition and the filling system, as well as the cooling system that can be seen in Fig. 8 .

\section{FE analysis}

An FE analysis of the battery cover was performed and the parameter values during the analysis were set according to Table 2. According to the simulation, filling time, weld line position, air traps, and warpage of the battery cover were provided [24], which may be a reference for the mold design, as shown in Fig. 9-12.

Fig. 9 shows that the mold is filled in $0.7 \mathrm{~s}$ and five gates are opened at the same time. The flow balance is good, the filling speed is fast, and there is no unstable flow, which ensures that the cavity can be completely and evenly filled 


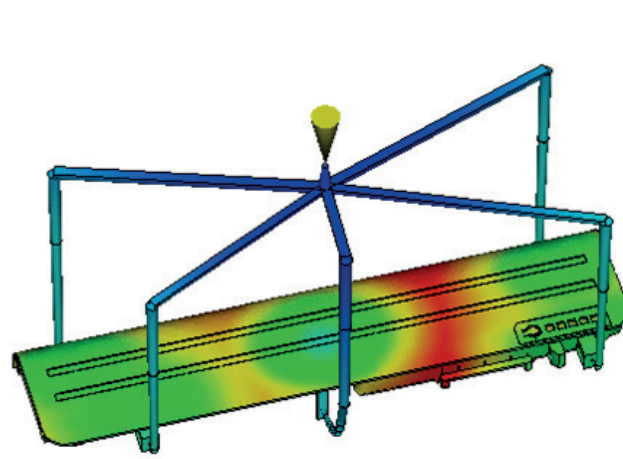

Full time
$=0.6967[\mathrm{~s}]$

[s]

0.6966

0.5225

0.3483

0.1742

0.0000

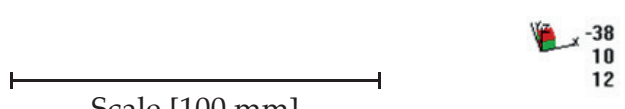

Fig. 9. Filling time

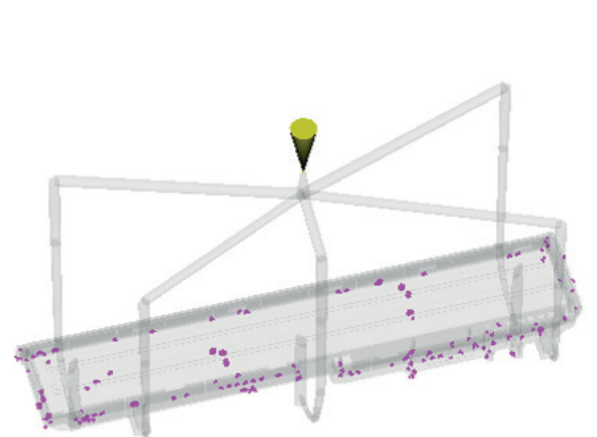

Air

traps

-38
10
12

Scale [100 mm]

Fig. 11. Air traps

T a b l e 2. Parameters used in Moldflow analysis

\begin{tabular}{l|c|c}
\hline \multicolumn{1}{c|}{ Parameter } & Factor & Value \\
\hline Melt temperature, ${ }^{\circ} \mathrm{C}$ & $\mathrm{A}$ & 280 \\
Mold temperature, ${ }^{\circ} \mathrm{C}$ & $\mathrm{B}$ & 70 \\
Injection time, s & $\mathrm{C}$ & 0.7 \\
Hold time, s & $\mathrm{D}$ & 2 \\
Holding pressure, $\mathrm{MPa}$ & $\mathrm{E}$ & 150 \\
\hline
\end{tabular}

thus preventing the overpressure phenomenon. It shows that the design of the gating system is reasonable and can meet the requirements of mold filling. Fig. 10 shows the location of the weld line, 7 weld lines appear on the battery cover. The gas in the cavity will affect the fusion of the melt, leading to the generation of weld lines. Therefore, a venting system should be provided in the mold design to improve the weld line of the plastic part. Fig. 11 shows the battery cover air traps, most of them were located on the edge of the battery cover. And these positions usually have parting surfaces, which will exhaust the accumulated air, so that air traps generally do not appear. Fig. 12 shows the battery cover warpage, the shape of the battery cover is a long strip, so the warpage mainly occurs in the $\mathrm{Z}$ direction. The maximum warpage value is $0.4202 \mathrm{~mm}$, which mainly occurs at both ends of the battery cover.

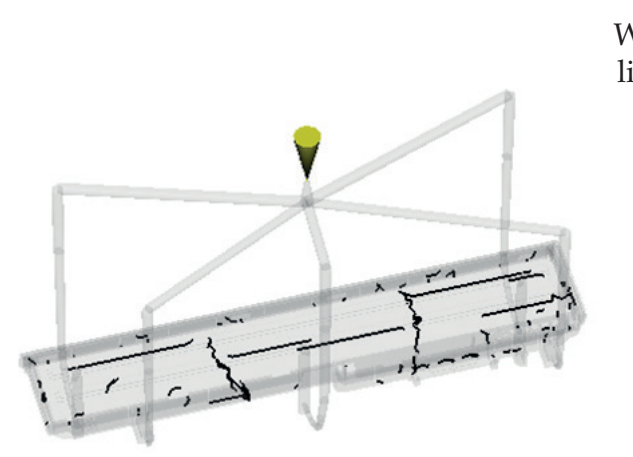

Weld

lines

$1 / 2+38$
$\times-38$
12

Fig. 10. Weld lines

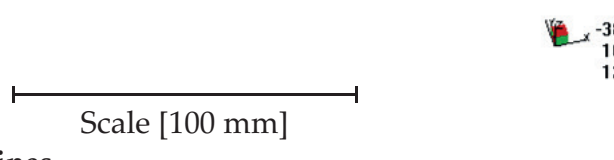

Deflection, all effects: Z Component

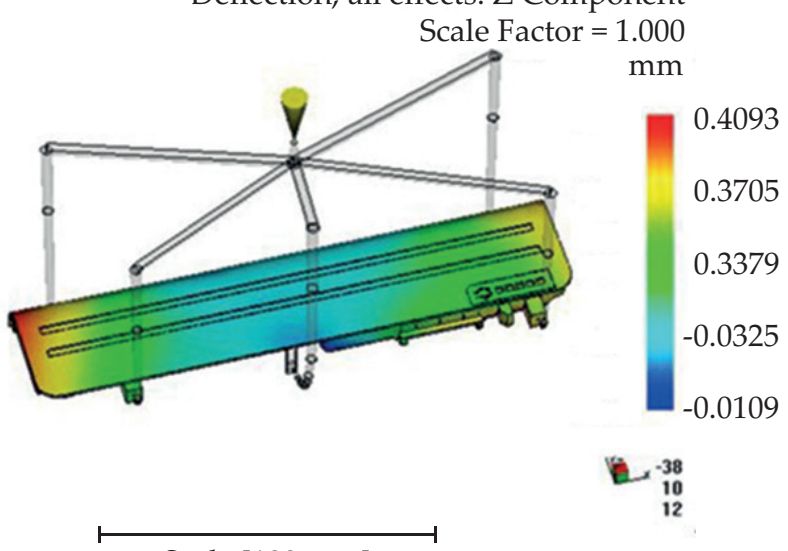

Fig. 12. Warpage deformation

\section{Mold design}

The three-dimensional model of the battery cover is imported into UG software, and the mold is designed in detail by using the Moldwizard module in UG software. The three-plate mold and a single cavity mold were used. The gating system adopts a latent horn gate. Cooling water channels were set in the cavity, core and slider. The internal undercuts of plastic parts are molded and ejected by the Bevel Pin, and the external undercuts are molded and ejected with the slider. The entire core consists of several inserts, and a large amount of gas generated during the molding process will be taken away through the gap between the inserts. The mold core, mold cavity, and venting system are shown in Figs. 13-15. The injection mold design is shown in Fig. 16.

\section{Optimization of process parameters}

By optimizing the mold design of the battery cover, most of the weld line in parts can be eliminated. The cooling water channel is set in the mold to prevent warping of the battery cover. However, in Fig. 12 it can be seen that the warpage deformation of the plastic part after forming was $0.6172 \mathrm{~mm}$, which still exceeds the allowable 


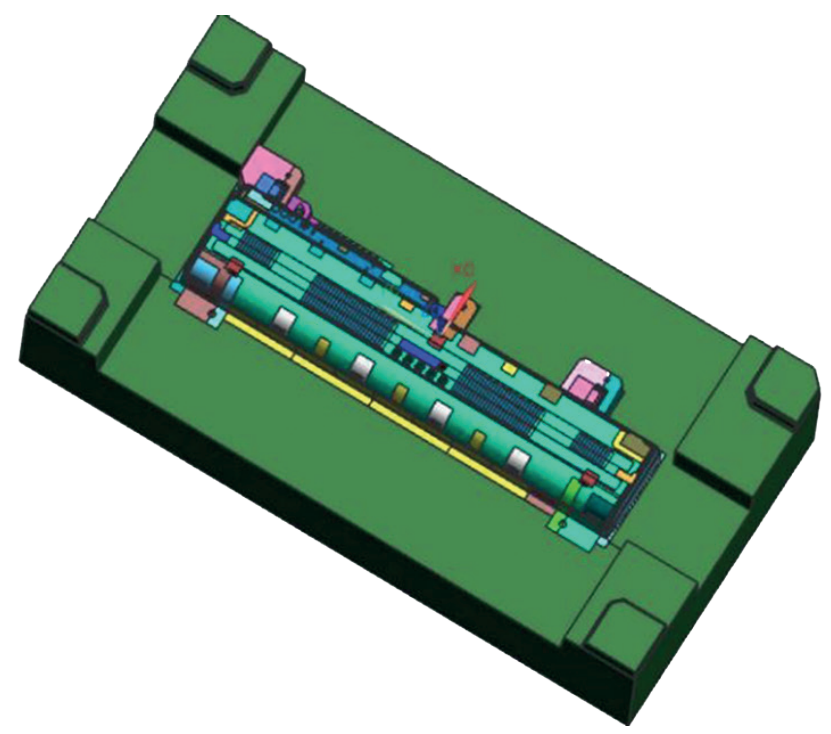

Fig. 13. Mold core

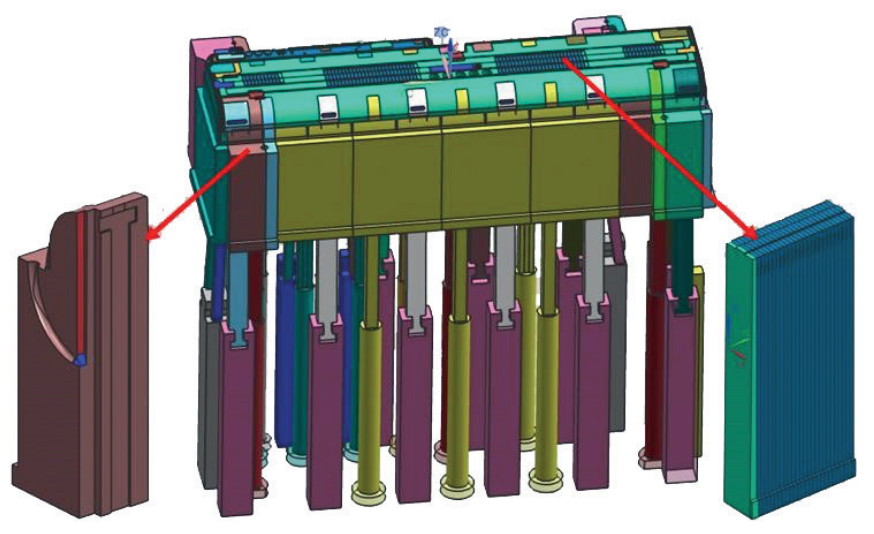

Fig. 15. Venting system

design requirements of the battery cover. Therefore, it was necessary to optimize the molding process parameters to improve the warping of the battery cover. Taguchi optimization technique is an experimental method to study multiple factors and multiple levels, it minimizes the number of experiments using different orthogonal arrays, which leads to reduction in time and cost [25].

\section{Selection of experimental factor level}

The main factors that affect the warpage of the battery cover during the molding process are melt temperature, mold temperature, injection time, hold time, and

T a b 1 e 3. Process factors and their levels selected in the orthogonal experiment

\begin{tabular}{c|c|c|c|c|c}
\hline Level & $\begin{array}{c}\text { Factor } \\
\text { A }\end{array}$ & $\begin{array}{c}\text { Factor } \\
\text { B }\end{array}$ & $\begin{array}{c}\text { Factor } \\
\text { C }\end{array}$ & $\begin{array}{c}\text { Factor } \\
\text { D }\end{array}$ & $\begin{array}{c}\text { Factor } \\
\text { E }\end{array}$ \\
\hline 1 & 280 & 70 & 0.7 & 2.0 & 100 \\
2 & 290 & 80 & 0.8 & 2.5 & 110 \\
3 & 300 & 90 & 0.9 & 3.0 & 120 \\
4 & 310 & 100 & 1.0 & 3.5 & 130 \\
\hline
\end{tabular}

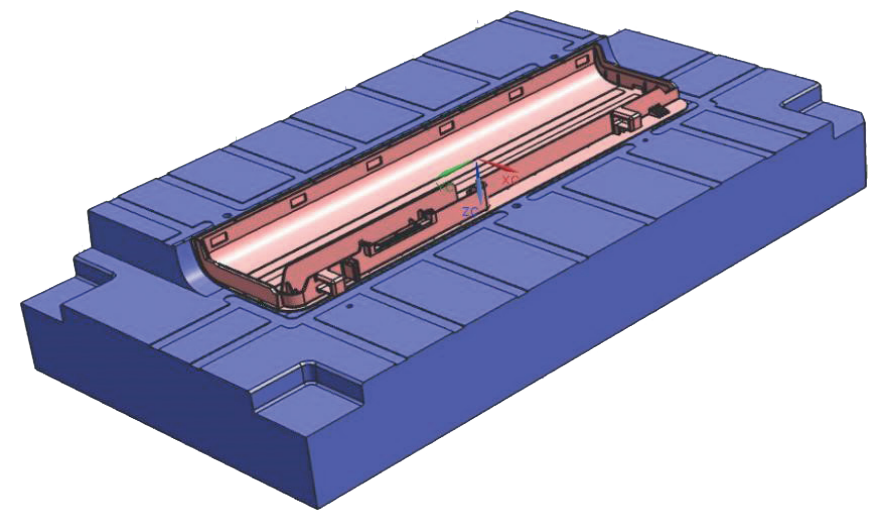

Fig. 14. Mold cavity

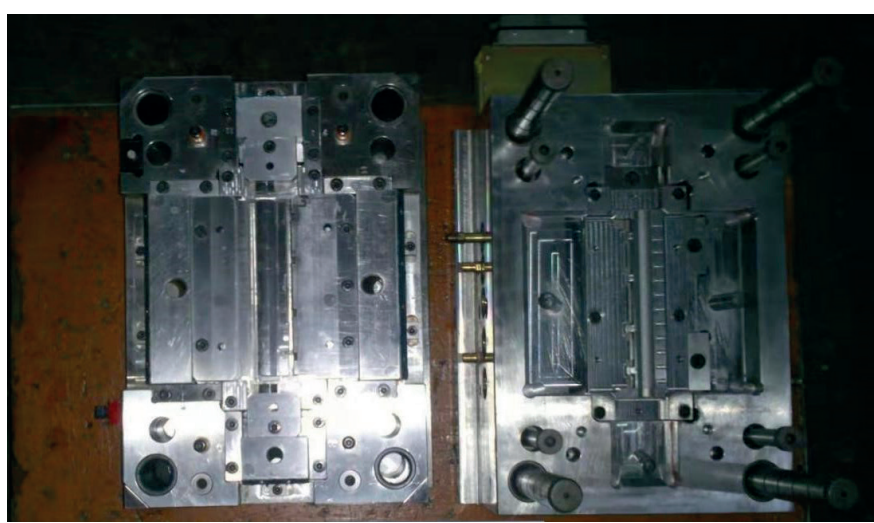

Fig. 16. Injection mold

holding pressure, which are referred to A, B, C, D, E factors, respectively. There is no interaction between the factors [26]. Taking as the number of factors selected in the orthogonal experiment, combined with the recommended parameters and empirical polycarbonate values, the four levels of each factor are evenly selected. The factor levels are presented in Table 3.

\section{Orthogonal experiment and analysis of results}

According to the factors and levels selected in the experiment, the deformation of the battery cover warpage was used as the orthogonal experiment evaluation index, and the orthogonal array L16 $\left(4^{5}\right)$ was selected for the experiment design [27]. From the process parameters listed in Table 3, 16 simulations were performed using Moldflow software to obtain the battery cover warpage deformation under 16 sets of different process parameters combinations.

In order to see the degree of influence of each factor on the warpage deformation intuitively, a range analysis was introduced. The range is the difference between the maximum and minimum values of the average value of 
$\mathrm{T}$ a b 1 e 4 . The experimental scheme and results

\begin{tabular}{c|c|c|c|c|c|c}
\hline $\begin{array}{c}\text { Trial } \\
\text { number }\end{array}$ & $\begin{array}{c}\text { Factor } \\
\text { A }\end{array}$ & $\begin{array}{c}\text { Factor } \\
\text { B }\end{array}$ & $\begin{array}{c}\text { Factor } \\
\text { C }\end{array}$ & $\begin{array}{c}\text { Factor } \\
\text { D }\end{array}$ & $\begin{array}{c}\text { Factor } \\
\text { E }\end{array}$ & $\begin{array}{c}\text { Warpage } \\
\text { mm }\end{array}$ \\
\hline 1 & 280 & 70 & 0.7 & 2.0 & 100 & 1.265 \\
2 & 280 & 80 & 0.8 & 2.5 & 110 & 1.132 \\
3 & 280 & 90 & 0.9 & 3.0 & 120 & 0.939 \\
4 & 280 & 100 & 1.0 & 3.5 & 130 & 1.139 \\
5 & 290 & 70 & 0.8 & 3.0 & 130 & 1.219 \\
6 & 290 & 80 & 0.9 & 3.5 & 100 & 0.959 \\
7 & 290 & 90 & 1.0 & 2.0 & 110 & 0.999 \\
8 & 290 & 100 & 0.7 & 2.5 & 120 & 1.209 \\
9 & 300 & 70 & 0.9 & 3.5 & 110 & 1.039 \\
10 & 300 & 80 & 1.0 & 2.0 & 120 & 0.975 \\
11 & 300 & 90 & 0.7 & 2.5 & 130 & 1.215 \\
12 & 300 & 100 & 0.8 & 3.0 & 100 & 0.985 \\
13 & 310 & 70 & 1.0 & 2.5 & 120 & 1.145 \\
14 & 310 & 80 & 0.7 & 3.0 & 130 & 1.225 \\
15 & 310 & 90 & 0.8 & 3.5 & 100 & 1.015 \\
16 & 310 & 100 & 0.9 & 2.0 & 110 & 1.045 \\
\hline & & & & & \\
\hline
\end{tabular}

a)

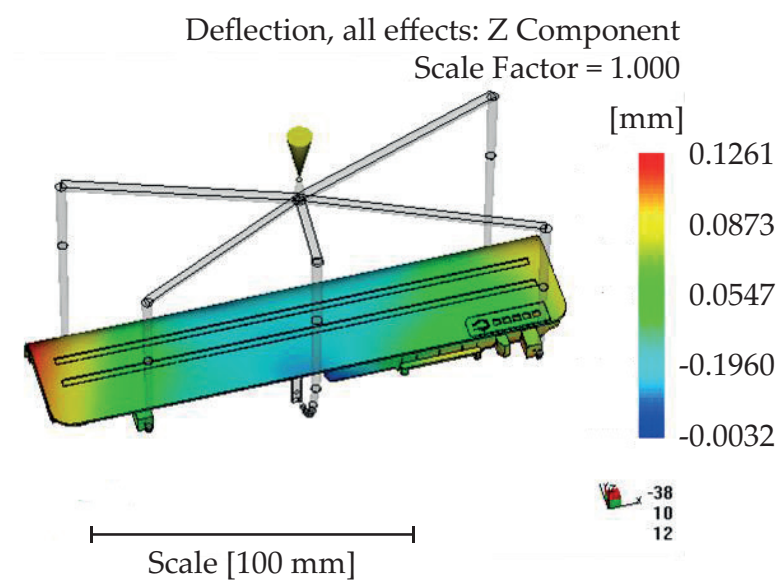

c)

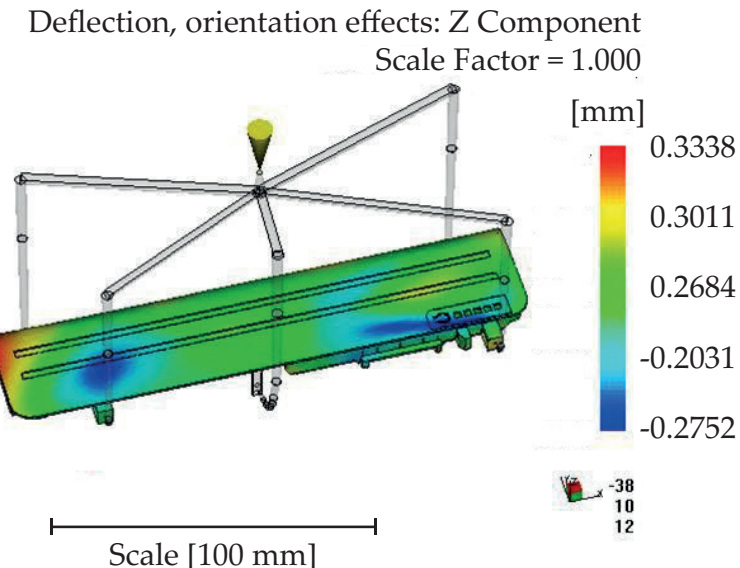

T a b l e 5. Range analysis

\begin{tabular}{c|c|c|c|c|c}
\hline Mean & $\begin{array}{c}\text { Factor } \\
\mathrm{A}\end{array}$ & $\begin{array}{c}\text { Factor } \\
\mathrm{B}\end{array}$ & $\begin{array}{c}\text { Factor } \\
\mathrm{C}\end{array}$ & $\begin{array}{c}\text { Factor } \\
\mathrm{D}\end{array}$ & $\begin{array}{c}\text { Factor } \\
\mathrm{E}\end{array}$ \\
\hline $\mathrm{K} 1$ & 1.119 & 1.167 & 1.229 & 1.071 & 1.056 \\
$\mathrm{~K} 2$ & 1.097 & 1.073 & 1.088 & 1.175 & 1.054 \\
$\mathrm{~K} 3$ & 1.054 & 1.042 & 0.995 & 1.092 & 1.067 \\
$\mathrm{~K} 4$ & 1.108 & 1.095 & 1.065 & 1.038 & 1.200 \\
Range & 0.065 & 0.125 & 0.234 & 0.137 & 0.146 \\
Sequence & 5 & 4 & 1 & 3 & 2 \\
\hline
\end{tabular}

the test results of each parameter at different levels [28]. The 16 groups of data in Table 4 were analyzed by the range analysis method, as shown in Table 5 . The greater the range value, the greater the influence of this factor on the index. Adjusting the value of the factor, the warpage of the battery cover will change correspondingly [29].

It can be seen from Table 5 that the degree of influence of the five process parameters on the warpage of the notebook battery cover is ranked as follows: injection time $>$ holding pressure $>$ hold time $>$ mold temperature $>$ melt temperature. It shows that the most important factors affecting the warpage of the battery cover are injection time and holding pressure, followed

b)

Deflection, differential shrinkage: Z Component Scale Factor $=1.000$

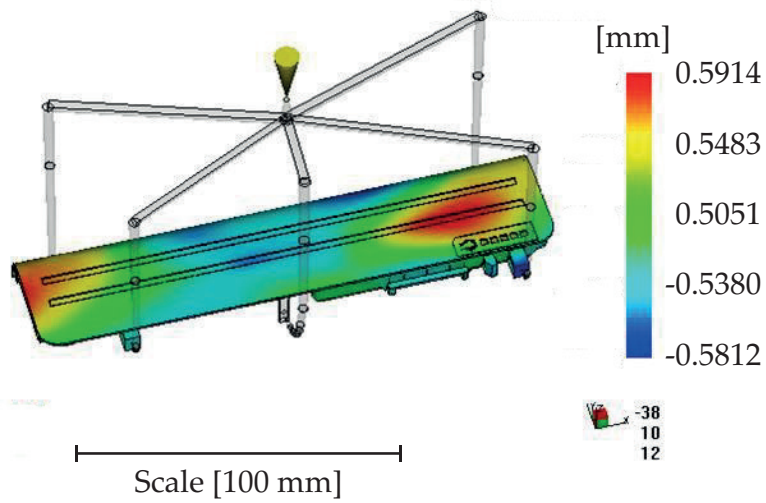

d)

Deflection, differential cooling: Z Component Scale Factor $=1.000$

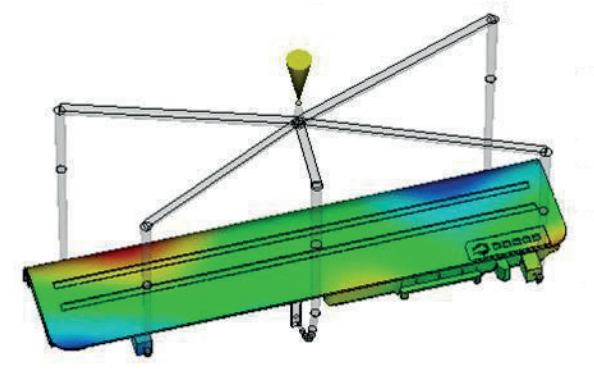

$[\mathrm{mm}]$ 0.0624 0.0434 0.0376 $-0.0242$ $-0.0018$ Scale $[100 \mathrm{~mm}]$

Fig. 17. Warpage in the optimal molding process parameters: a) total amount of warpage, b) warpage caused by regional shrinkage, c) warpage caused by molecular flow orientation, d) warpage caused by uneven cooling 
by injection time and mold temperature, and the melt temperature has the least effect. The optimal parameters of the battery cover molding process are $\mathrm{A}_{3} \mathrm{~B}_{3} \mathrm{C}_{3} \mathrm{D}_{4} \mathrm{E}_{2^{\prime}}$, the melt temperature is $300^{\circ} \mathrm{C}$, the mold temperature is $90^{\circ} \mathrm{C}$, the injection time is $0.9 \mathrm{~s}$, the hold time is $3.5 \mathrm{~s}$, and the holding pressure is $110 \mathrm{MPa}$.

The optimal molding process parameters were input into Moldflow software for simulation. Figure 17 shows the warpage deformation under the optimal parameters of the molding process. Figure 17a is the total warpage deformation. Figures $17 b-d$ show the warpage deformation caused by uneven cooling, area shrinkage and molecular flow orientation, respectively. With optimal parameters of the molding process, the total warpage deformation is $0.1293 \mathrm{~mm}$. Compared to the warpage deformation of $0.4202 \mathrm{~mm}$ before optimizing the process parameters, it was reduced by $69 \%$, which means a great reduction in the warpage deformation of the battery cover. Due to the melt, the temperature rises from $280^{\circ} \mathrm{C}$ to $290^{\circ} \mathrm{C}$, the volume of the melt increases and the interaction between molecules is weakened, thereby improving the fluidity of the melt and making the mold filling better. The mold temperature was increased from $70^{\circ} \mathrm{C}$ to $90^{\circ} \mathrm{C}$, the plastic parts shrink evenly, and the warpage of the battery cover was smaller. The injection time is inversely proportional to the injection speed. When the injection speed is too high, the sheer force of the melt entering the cavity increases, which will cause a difference between the molecular orientations parallel to the flow direction and perpendicular to the flow direction, resulting in orientation stress and causing warpage deformation. Therefore the injection time was increased from 1 to $1.2 \mathrm{~s}$, and the injection speed was also reduced, so that the stress concentration in the melt was reduced, thereby reducing the warpage. Extending the hold time and increasing the holding pressure can not only improve the shrinkage of the plastic parts, but also eliminate the air traps in the plastic parts. From the comparison of Figs. 17b-d, it can be seen that the warpage deformation caused by the region shrinkage is the largest, the warpage deformation due to the molecular flow orientation is the second, and the warpage deformation caused by the uneven cooling is the smallest. Shrinkage is the main cause of warpage deformation of plastic parts.

\section{Battery cover manufacturing}

A Sumitomo SE130HSZ high-speed injection molding machine was used. The injection mold was installed in the injection molding machine, and the dried PC raw material fed into the barrel [30]. The process parameters were set to the optimal molding process parameters obtained before, and we performed the injection molding of the battery cover, as shown in Fig. 18. The produced battery cover is shown in Fig. 19. It can be seen that there are no visible weld lines and air traps on the surface of the battery cover. Twelve pieces were randomly selected

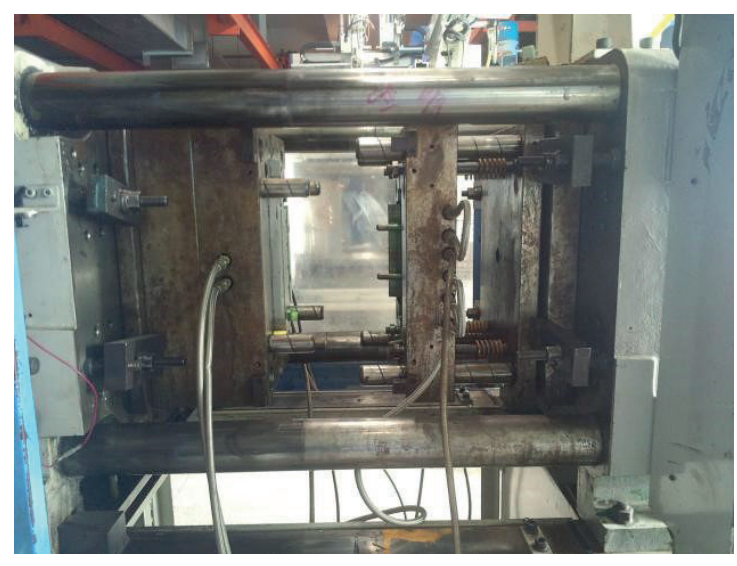

Fig. 18. Manufacturing of battery cover

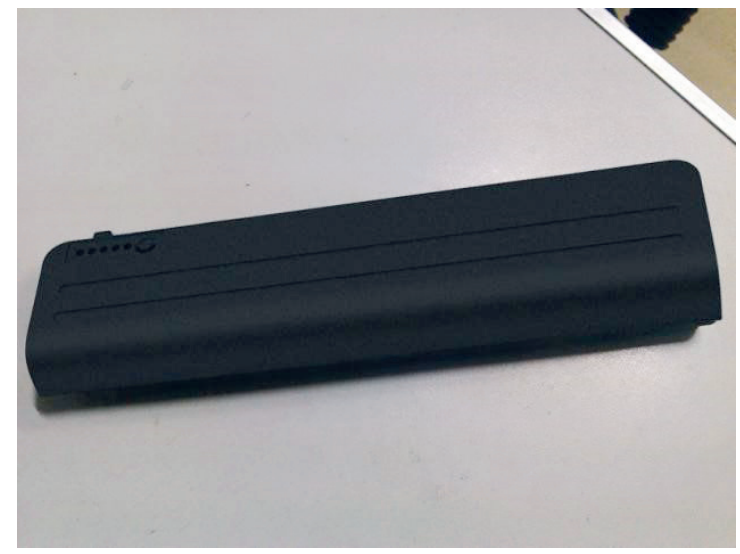

Fig. 19. Battery cover

and measured using a three-dimensional instrument [31]. The maximum value of warpage deformation did not exceed $0.13 \mathrm{~mm}$, which met the design requirements that the amount of warpage did not exceed $0.2 \mathrm{~mm}$. It was confirmed that the improvement scheme of the mold design and molding process parameters were correct.

\section{CONCLUSIONS}

In this study, the mold design and injection process parameters were improved to optimize the warpage of the battery cover. The following conclusions were drawn:

- Improved mold design and injection molding parameters reduced the warpage of the battery cover by more than $69 \%$. There were no weld lines and air pockets on the surface of the battery cover, and the improvement scheme effectively increased the molding quality of the battery cover. The manufacturing of the battery cover confirmed the correctness of the improvement plan. This solution can provide a reference for injection molding of similar parts.

- The mold of the notebook battery cover consisted of a three-plate mold and single-cavity mold was used. Selected latent horn gate set the Rib dosing system between flow gate and plastic part. Cooling water channels were set on the cavity, core and slider. The entire core was equipped with several inserts to exhaust the 
gas during the molding process. The internal undercuts of the plastic parts were formed and ejected by the Bevel Pin, and the external undercuts were formed and ejected with the slider.

- The optimal parameters of the battery cover molding process are $\mathrm{A}_{3} \mathrm{~B}_{3} \mathrm{C}_{3} \mathrm{D}_{4} \mathrm{E}_{2}$, the melt temperature was $300^{\circ} \mathrm{C}$, the mold temperature $90^{\circ} \mathrm{C}$, the injection time was $0.9 \mathrm{~s}$, the hold time $3.5 \mathrm{~s}$, and the holding pressure $110 \mathrm{MPa}$. The warpage deformation caused by the region shrinkage was the largest, the warpage deformation due to the molecular flow orientation was the second, and the warpage deformation caused by the uneven cooling was the smallest. Shrinkage is the main cause of warpage deformation of plastic parts.

\section{ACKNOWLEDGMENTS}

This work was supported by a Grant from National Science Fund of China (51475352).

\section{REFERENCES}

[1] Chiang Y.C., Cheng H.C., Huang C.F. et al.: The International Journal of Advanced Manufacturing Technology 2011, 55, 517. https://doi.org /10.1007/s00170-010-3106-4

[2] Slaviero C., Weiss K., Woodman D.: SAE Technical Paper 2001, 2001-01-1272 https://doi.org/10.4271/2001-01-1272

[3] Shi H., Wang X., Xie S.: International Polymer Process 2012, 27, 341. https://doi.org/10.3139/217.2542

[4] Fangfang H.E., Zhou Z., Jiang B.: Acta Materiae Compositae Sinica 2013, 30, 128.

[5] Song M.C., Liu Z., Wang M.J. et al.: Journal of Materials Processing Technology 2007, 187-188, 668. https://doi.org/10.1016/j.jmatprotec.2006.11.103

[6] Lee B.H., Kim B.H.: Polymer-Plastics Technology and Engineering 1995, 34, 793. https://doi.org/10.1080/03602559508009600

[7] Xie P., Guo F., Jiao Z. et al.: Materials \& Design 2014, 53, 366. https://doi.org/10.1016/j.matdes.2013.06.071

[8] Yen C., Lin J.C., Li W., Huang M.F.: Journal of Materials Processing Technology 2006, 178, 1. https://doi.org/10.1016/j.jmatprotec.2005.02.153

[9] Hassan H., Regnier N., Pujos C. et al.: Applied Thermal Engineering 2010, 30, 1547. https://doi.org/10.1016/j.applthermaleng.2010.02.025

[10] Kramschuster A., Cavitt R., Ermer D. et al.: Plastics, Rubber and Composites 2006, 35, 198. https://doi.org/10.1179/174328906X128199

[11] Guo Z., Ruan X., Peng Y. et al.: Journal of Materials Engineering and Performance 2002, 11, 138. https://doi.org/10.1361/105994902770344196

[12] Matin I., Hadzistevic M., Hodolic J. et al.: The International Journal of Advanced Manufacturing Technology 2012, 63, 595.

\section{https://doi.org/10.1007/s00170-012-3926-5}

[13] Ozcelik B., Sonat I.: Materials \& Design 2009, 30, 367. https://doi.org/10.1016/j.matdes.2008.04.053

[14] Lotti C., Ueki M.M., Bretas R.E.S: Journal of Injection Molding Technology 2002, 6, 157.

[15] Patcharaphun S., Mennig G.: Polymer-Plastics Technology and Engineering 2016, 45, 759. https://doi.org/10.1080/03602550600611651

[16] Gao Y., Wang X.: The International Journal of Advanced Manufacturing Technology 2008, 37, 953. https://doi.org/10.1007/s00170-007-1044-6

[17] Shi H., Gao Y., Wang X.: The International Journal of Advanced Manufacturing Technology 2010, 48, 955. https://doi.org/10.1007/s00170-009-2346-7

[18] Moayyedian M., Abhary K., Marian R: CIRP Journal of Manufacturing Science and Technology 2018, 21, 150. https://doi.org/10.1016/j.cirpj.2017.12.001

[19] Xu A., Huang L.: Plastics 2017, 46, 110.

[20] Park H., Cha B., Cho S. et al.: The International Journal of Advanced Manufacturing Technology 2016, 83, 2057. https://doi.org/10.1007/s00170-015-7694-x

[21] Farshi B., Gheshmi S., Miandoabchi E.: Materials \& Design 2010, 32, 414. https://doi.org/10.1016/j.matdes.2010.06.043

[22] Jedsadaratanachai W., Jayranaiwachira N., Promvonge P.: Chinese Journal of Chemical Engineering 2015, 23, 342. https://doi.org/10.1016/j.cjche.2014.11.006

[23] Bociąga E., Jaruga T., Lubczyńska K., Gnatowski A.: Archives of Materials Science \& Engineering 2010, 44, 28.

[24] Oktem H., Erzurumlu T., Uzman I.: Materials \& Design 2007, 28, 1271. https://doi.org/10.1016/j.matdes.2005.12.013

[25] Larpsuriyakul P., Fritz H.G.: Polymer Engineering and Science 2011, 51, 411. https://doi.org/10.1002/pen.21849

[26] Deng Y.M., Zhang Y., Lam Y.C.: Materials \& Design 2010, 31, 2118. https://doi.org/10.1016/j.matdes.2009.10.026

[27] Azdast T, Behravesh A.H., Mazaheri K. et al.: Polimery 2008, 53, 304. https://doi.org/10.14314/polimery.

[28] Zhou H., Li D.: Polymer-Plastics Technology and Engineering 2005, 44, 603. https://doi.org/10.1081/PTE-200057781

[29] Wu H., Zhao Z., Sha J.: Mechanics of Time-Dependent Materials 2009, 13, 233. https://doi.org/10.1007/s11043-009-9086-9

[30] Gao Y., Wang X.: Journal of Materials Processing Technology 2009, 209, 1302. https://doi.org/10.1016/j.jmatprotec.2008.03.048

[31] Sánchez R., Aisa J., Martinez A. et al.: Measurement 2012, 45, 1051.

https://doi.org/10.1016/j.measurement.2012.01.039

Received 17 III 2021. 